\title{
Progress Toward a National Water Census
}

Increasing demand and competition for limited regional water resources make it difficult to ensure adequate water availability for both human and ecological needs now and into the future. Recognizing the need to improve the tools and information that are available to effectively evaluate water-resource availability, the U.S. Geological Survey (USGS) identified a National Water Census (NWC) as one of its six core science directions for the decade 2007-17 (U.S. Geological Survey, 2007). In 2009, the SECURE Water Act (Public Law 111-11) authorized the USGS to develop a national water availability and use assessment program that would update the most recent national assessment of the status of water resources in the United States (U.S. Water Resources Council, 1968, 1978) as well as develop the science to improve forecasts of water availability and quality for future needs.

By evaluating large-scale effects of changes in land use and land cover, water use, and climate on occurrence and distribution of water, water quality, and human and aquaticecosystem health, the NWC will also help to inform a broader initiative by the Department of the Interior, WaterSMART (Sustain and Manage America's Resources for Tomorrow), which provides multiagency funding to pursue a sustainable water supply for the Nation as directed under the SECURE Water Act. Through the NWC, the USGS actively engages Federal, regional, and local stakeholders to identify research priorities and leverages current studies and program activities to provide information that is relevant at both the national and regional scales.

The NWC will produce a current, comprehensive scientific assessment of the factors that influence water availability by (1) developing nationally consistent datasets that reflect the status and trends of major water budget components (diagram below), as well as water use, for the Nation; (2) improving the current understanding of flow requirements for ecological purposes; and (3) evaluating water-resource conditions in selected river basins, or Geographic Focus Areas, where competition for water is elevated. Future research goals of the NWC include (1) evaluating the relations between water supply and quality for both human and ecological uses, including the potential use of impaired water supplies; (2) development of Geographic Focus Area studies in additional basins; and (3) the continued improvement of uncertainty analysis.

Much of the information developed as part of the NWC is derived from models, statistical estimation techniques, and other transformation processes. The National Water Census Data Portal has been developed to allow users to access a comprehensive and nationally consistent interactive map interface to download data visualizations, retrieve stand-alone data for further analysis, or integrate multiple datasets with built-in and downloadable data-analysis tools.
Components of a simple water budget for part of a watershed (modified from Healy and others, 2007).

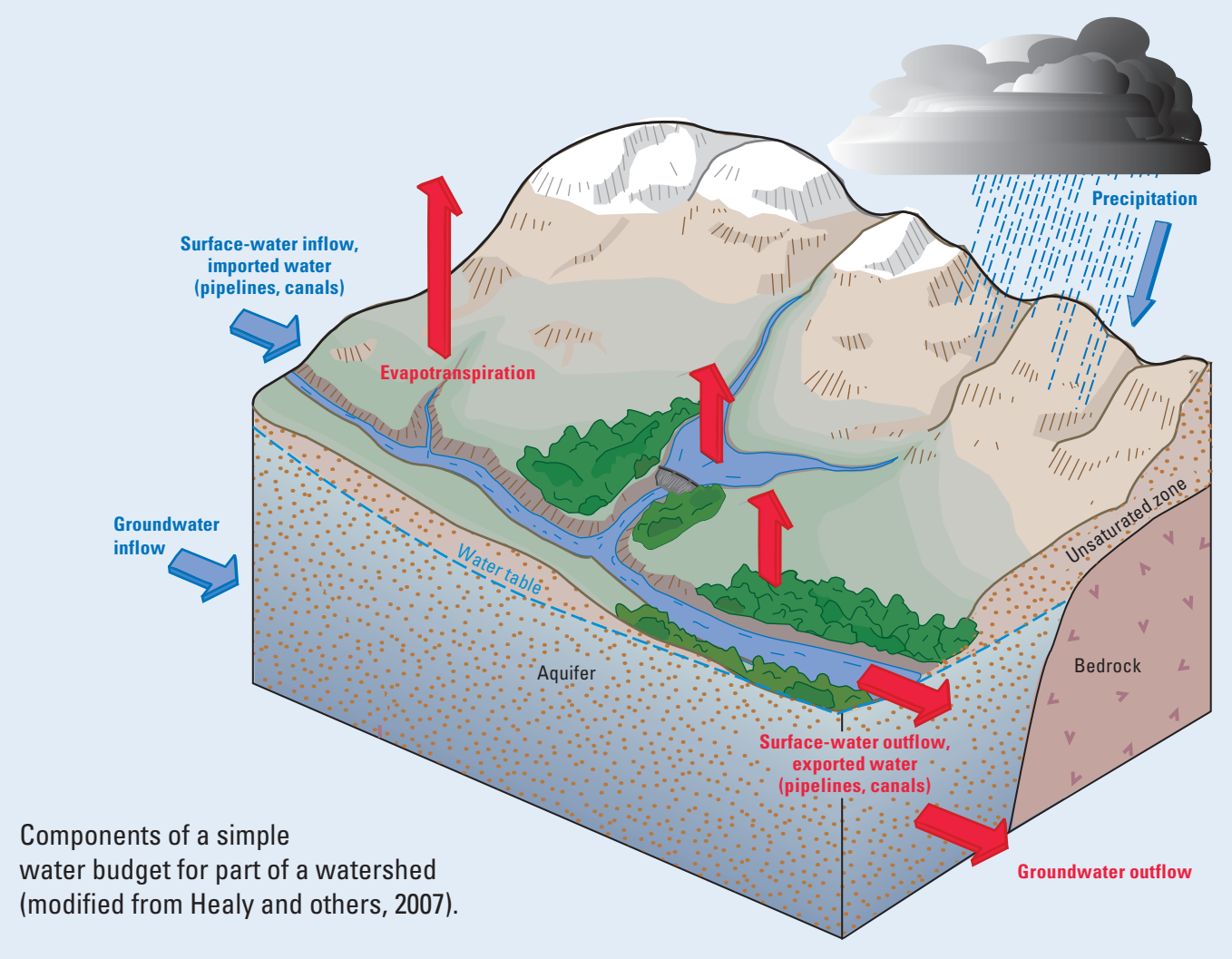




\section{Developing a National Water Budget}

Data and other information produced as part of the NWC can be used to define the components of a water budget; unfortunately, consistent data for many water-budget components are not currently available either regionally or nationally. The unifying goal of the NWC is to develop and improve estimates of waterbudget components at consistent spatial (basin) and temporal (monthly) scales. This goal will be achieved through a series of topical area studies that are designed to quantify the amount of water that resides in, or is moving through, water budgets.

\section{Topical Areas}

As part of the NWC, the USGS will conduct studies that focus on streamflow, groundwater, precipitation, evapotranspiration, and water use to develop and improve the data needed to achieve a comprehensive and up-to-date assessment of water availability at both national and basin scales. An additional topical area study will advance the science of ecological flow by quantitatively examining the relations between water availability and healthy ecosystems.

Each topical area study seeks to enhance available data and associated information through the research and development of new methodologies, improving data accessibility, and quantifying and reducing data uncertainty. In addition to providing a basis for national indicators of water flow and storage for the NWC, these studies will support analyses of water availability by local and regional agencies and will contribute to research quantifying national and global water cycles.

\section{Geographic Focus Area Studies}

Competition for water resources is focused regionally where competing water needs - either human needs (for example, potable water, irrigation, energy development, industrial use) or flow requirements for healthy ecosystems are outpacing current supplies. As a counterpart to the topical area studies, a series of Geographic Focus Area studies, or regional assessments, will provide opportunities to test and improve approaches for quantifying water-budget components and pilot the application of regional water budgets to the watermanagement challenges of large river basins. These studies will also provide an opportunity to inform and "ground truth" NWC methods and applications with local information.

The first three Geographic Focus Area studies are underway in the Apalachicola-Chattahoochee-Flint, Colorado, and Delaware River Basins (map upper right); specific basin research and products include: water-use databases that estimate current and historical trends, including consumptive use; developing a tool to estimate streamflow at ungaged streams and coupling surface- and groundwater flow models; and developing decision support systems and ecological models to predict changes in fish and mussel species associated with climate and land-use change and water use.

Three new Focus Area studies will begin in October 2015 in the Red River and Rio Grande Basins, and the Coastal Basins of the Carolinas. Planned research includes impacts of dust on snow, refinement and coupling of groundwater and surfacewater models, and development of methods to evaluate agricultural irrigation.

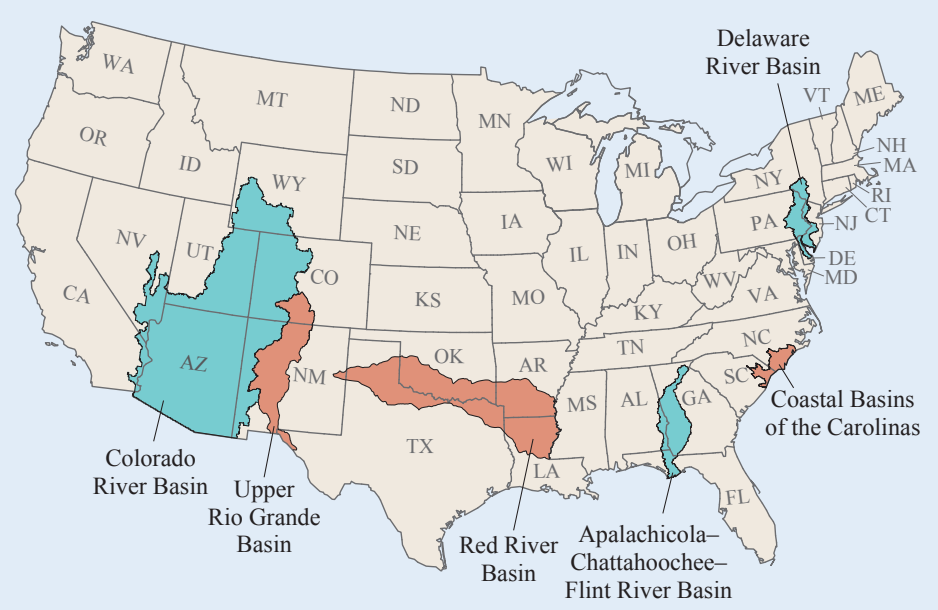

\section{References}

Healy, R.W., Winter, T.C., LaBaugh, J.W., and Franke, O.L., 2007, Water budgets-Foundations for effective waterresources and environmental management: U.S. Geological Survey Circular 1308, 90 p., available at http://pubs.usgs.gov/ circ/2007/1308/.

U.S. Geological Survey, 2007, Facing tomorrow's challengesU.S. Geological Survey science in the decade 2007-2017: U.S. Geological Survey Circular 1309, 70 p., available online at http://pubs.usgs.gov/circ/2007/1309/.

U.S. Water Resources Council, 1968, The Nation's water resources: Washington, D.C., U.S. Government Printing Office, $480 \mathrm{p}$.

U.S. Water Resources Council, 1978, The Nation's water resources 1975-2000-Second National Water Assessment: Washington, D.C., U.S. Government Printing Office, 768 p.

\section{Additional Information and Contacts}

Detailed information about the current status and activities of the National Water Census can be found in U.S. Geological Survey Circular 1384, "Progress Toward Establishing a National Assessment of Water Availability and Use." This publication is available online at http://pubs. usgs.gov/circ/1384/. For additional information, please visit http://water.usgs.gov/watercensus/ or contact:

Sonya Jones, Program Coordinator

National Water Availability and Use Science Program

U.S. Geological Survey

1770 Corporate Drive, Suite 500

Norcross, GA 30093

Phone: 678-924-6606

E-mail: sajones@usgs.gov

Eric J. Evenson, Program Office

Water Mission Area

U.S. Geological Survey

3450 Princeton Pike, Suite 110

Lawrenceville, NJ 08648

Phone: 609-771-3904

E-mail: eevenson@usgs.gov
ISSN 2327-6932 (online) http://dx.doi.org/10.3133/fs20153045 